https://doi.org/10.15407/ufm.21.03.319

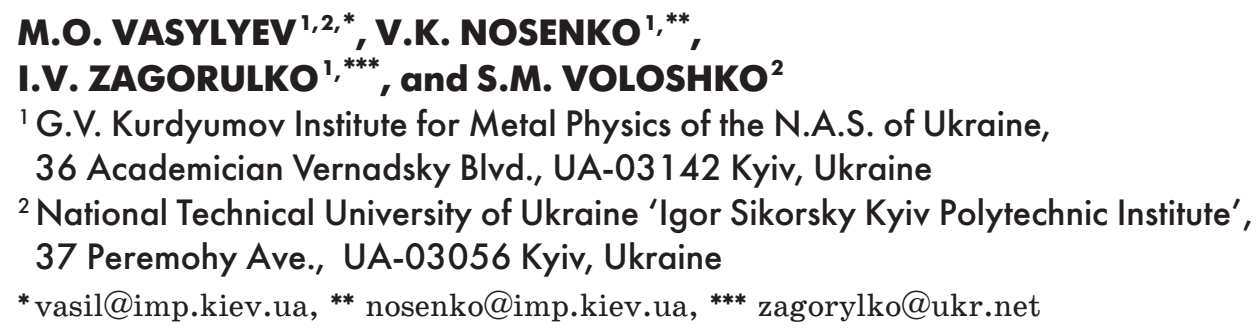

\title{
NANOCRYSTALLZATION OF AMORPHOUS Fe-BASED ALLOYS UNDER SEVERE PLASTIC DEFORMATION
}

\begin{abstract}
The literature data on the problem of modification of the structure and properties of the Fe-based rapid-quenched alloys by various methods of severe plastic deformation (SPD) are reviewed. The SPD methods such as Bridgman cell torsion, ball-mill processing and high-frequency shock treatment as well as their advantages and disadvantages are considered. By examples of a large number of amorphous Fe-based alloys, the influence on their structure and properties of each of the considered SPD methods is analysed. Based on the obtained data, the mechanism of deformation nanocrystallization of amorphous alloys is proposed.
\end{abstract}

Keywords: amorphous alloys, severe plastic deformation, shear bands, nanocrystallization, mechanical properties.

\section{Introduction}

Metallic materials, where the crystal grain sizes vary from tens to several hundred nanometers, are the objects of increased interest for both theoretical and experimental researchers [1-6]. Innovative technologies that provide controlled milling of crystal grains to the nanometer range $(<100 \mathrm{~nm})$ are a powerful tool for creating new functional materials

Citation: M.O. Vasylyev, V.K. Nosenko, I.V. Zagorulko, and S.M. Voloshko, Nanocrystallization of Amorphous Fe-Based Alloys under Severe Plastic Deformation, Progress in Physics of Metals, 21, No. 3: 319-344 (2020) 
with unique properties and performance characteristics. Comprehensive studies of nanocrystalline metals and alloys have shown that in comparison with their microcrystalline counterparts, a higher strength and yield limit as well as higher resistance to wear and corrosion characterize them. Along with an impressive increase in strength, the reduction of the grain size to the nanometer level leads to a change in fundamental, commonly structurally insensitive characteristics, such as elastic moduli, Curie and Debye temperatures, saturation magnetization, etc., which opens up promising prospects for improving existing and creating new constructional and functional materials.

One of the most effective ways to transform the structure of materials and form a nanocrystalline (NC) structure is the use of severe plastic deformation (SPD). The essence of this method is the effect on the material of high-degree plastic deformation $(e>1)$ at relatively low homologous temperatures. Usually, the SPD is carried out under conditions of high pressure with a large static component, which prevents the destruction of the sample. To define and denote the severe plastic deformation, the author of Ref. [7] proposed the term 'megaplastic deformation'. The most common ways to create giant deformation values of bulk metal materials are torsion under pressure in the Bridgman chamber, flat-channel angular compression (pressing), screw extrusion, and accumulated rolling.

The SPD method at relatively low homologous temperatures is an effective way for structural transformation in the volume and on the surface of metals and alloys, particularly, due to the nanocrystal structure formation [2, 8]. As believed, the mechanism of SPD-induced metal hardening is based on the grain shattering and the nonequilibrium state of grain boundaries having a high level of local internal stresses. The quantity and distribution of dislocations, as well as the interaction between them, play an important role. The significant increase of the dislocation density and subsequent change of the dislocation structure at the SPD cause the formation of the internal subgrain structure and then the nanoscale grains. In recent years, the SPD methods have become widespread and the basis for the creation of new technologies for the production of nanostructured metals and alloys for various technical industries. Such materials include amorphous metal alloys (AMA) as well (in the literature, also occurs as amorphous metallic alloys).

The amorphous metal (or metallic) alloys incorporate a class of materials, which do not have a crystalline structure. In comparison with crystalline analogues of the same chemical composition, these materials are possessed of the increased strength, elastic elongation, corrosion resistance etc. The iron- and nickel-based amorphous and nanocrystalline alloys belong to the class of magnetically soft materials and have much better magnetic characteristics as compared to the crystalline an- 
alogues. Since the appearance of first amorphous systems, the most attention has been paid to the Fe-based amorphous alloys due to the promising prospects for application as magnetically soft, high-strength, and corrosion-resistant materials. Initially, simple $\mathrm{Fe}-\mathrm{B}$ systems with different boron concentrations were investigated. With the further improvement of the technology of production of amorphous ribbons by the method of rapid quenching of melts (so-called 'spinning' method), the complex alloys with the addition of $\mathrm{Si}, \mathrm{Ni}, \mathrm{Cu}, \mathrm{Nb}, \mathrm{Mo}, \mathrm{Cr}, \mathrm{P}, \mathrm{Y}$ were investigated. Numerous studies showed that under certain heat-treatment regimes, amorphous alloys tend towards the crystallization with the formation of nanocrystals.

The most striking example is the $\mathrm{Fe}-\mathrm{Si}-\mathrm{B}-\mathrm{Cu}-\mathrm{Nb}$ amorphous alloy, which is characterized by several times higher magnetic permeability at normal and high magnetization reversal frequencies as compared with permalloy, alsifer (sendust), ferrites, and other industrial crystalline soft magnetic materials [9]. This alloy is widely used in instrumentation and electrical engineering. The unique magnetic properties of the FINEMET alloy are mainly due to the precipitation (in the amorphous matrix) of the nanocrystalline b.c.c.-Fe-(16-18) at.\% Si b.c.c. $\alpha$-phase, ordered by $\mathrm{DO}_{3}$-type (volume fraction $\approx 40-50 \%$ ), which is formed during control annealing of the initial amorphous alloy obtained by quenching from the melt [10]. However, in some cases, this alloy is required to achieve not only high magnetic but also mechanical characteristics, particularly high strength [11].

In recent years, much attention has been paid to studies of changes in the structural and phase states of amorphous alloys, which do not contain such structural defects as dislocations and grain boundaries, under SPD conditions. Determining the mechanism of formation of the deformation structure in amorphous metal alloys and studying the features of its structure are one of the most important and interesting ways to modify the structure and properties of such materials. The results of recent studies have shown that the SPD of amorphous alloys can be one of the controlled methods for obtaining nanocrystalline materials with new properties. This method makes it possible to obtain a nanocrystalline state in alloys of a certain chemical composition, which could not be achieved by the method of traditional heat treatments. One of the advantages of nanocrystallization in SPD is the ability to form amorphouscrystalline compositions with more perfect grain boundaries. The SPD combined with subsequent annealing is effective for obtaining nonporous nanocrystalline materials, including bulk ones. Recent studies showed that strain crystallization of AMA can help improve their plastic properties.

The studies of the strain crystallization of AMA at room temperatures have been carried out mainly using two SPD methods: the first one deals with the conditions of the shear bands (or, more generally, a 
strain localization') under pressure (in the Bridgman's chamber), and the second one consists in the treatment in low- and high-energy ball mills. Firstly, the phenomenon of formation of 10-15 nm crystals in amorphous ribbon of $\mathrm{Fe}_{81} \mathrm{Si}_{7} \mathrm{~B}_{12}$ alloy at large shear strain under pressure has been observed in Ref. [12]. Authors [13] showed that the same SPD regime for $\mathrm{Fe}_{80} \mathrm{~B}_{20}$ amorphous ribbon also results to the formation of nanocrystals $(5-15 \mathrm{~nm})$, the amount of which increases as the strain enhances. The strain crystallization during torsion under pressure was also detected in amorphous Al-based ribbons [14, 15]. The study of nanocrystallization, which occurs during the processing of pieces of amorphous ribbons in ball mills, is also of great interest. For example, the formation of nanocrystals was also revealed during the processing of $\mathrm{Fe}-\mathrm{B}$ AMA systems [16-21].

As known, the AMA of $\mathrm{Fe}-\mathrm{Cu}-\mathrm{Nb}-\mathrm{Si}-\mathrm{B}$ (FINEMET) system, obtained by the method of rapid quenching of melt, after the thermal treatment in amorphous nanocrystalline state, possess the soft magnetic properties causing their wide practical applications. The general regularities of thermal nanocrystallization of the iron-based AMA are mainly established [22-28].

This review presents examples of effective modification of the structure and properties of fast-quenched amorphous iron-based alloys by such methods of severe deformation as torsion under pressure in the Bridgman chamber, processing in ball mills, and high-frequency shock treatment. In this regard, it is of interest to analyse the SPD impact on the changes that occur in the amorphous matrix structural characteristics, which provides the achievement of a complex of high magnetic and mechanical properties.

An object of the study in this review deals with amorphous Fe-based alloys. This is because, on the one hand, these alloys are studied systematically, and, on the other hand, they are known as those widely used in practice.

To analyse the literature for each of the methods, we keep up a chronological order.

\section{Torsion under Pressure in the Bridgman's Chamber}

In this section, we consider works dealing with the study of the peculiarities of the deformation process of amorphous alloys of the $\mathrm{Fe}-\mathrm{B}$ system depending on the SPD degree, which is achieved in the Bridgman chamber by sequential increasing the number of rotations of a moving anvil during torsion under high quasi-hydrostatic pressure (Bridgman anvil). This method of severe torsion under pressure refers to the methods of megaplastic deformation [29]. Below, we present examples of 
Fig. 1. The microstructure of $\mathrm{Fe}_{81} \mathrm{~B}_{13} \mathrm{Si}_{6}$ alloy in the transmission electron microscopy (TEM) bright-field image [30]

works where the method of severe torsion under pressure applied for amorphous Fe-based ribbons at room temperature results to the formation of nanocrystals in their structure.

In the work [30], using the

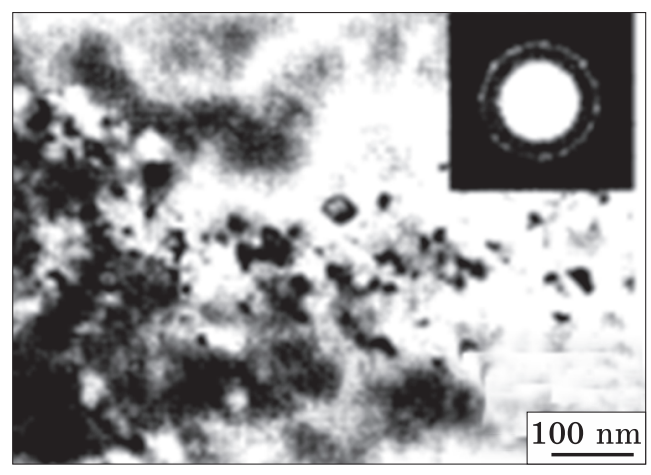
method of severe torsion under pressure of $4 \mathrm{GPa}$, authors processed amorphous $\mathrm{Fe}_{81} \mathrm{~B}_{13} \mathrm{Si}_{6}$-composition ribbon of $30 \mu \mathrm{m}$. The samples represented discs of $3 \mathrm{~mm}$ in diameter and $0.24 \mathrm{~mm}$ in thickness. The truly logarithmic strain was defined as $\varepsilon=\ln (\Theta r l)$; here, $\Theta$ - rotation angle of anvil (in rad), $r$ - radius of the sample, $l-$ thickness of disk. The sample was deformed at $20^{\circ} \mathrm{C}, 200{ }^{\circ} \mathrm{C}$, and $400{ }^{\circ} \mathrm{C}$. After the low deformation level (up to $\varepsilon=4$ ) at $20^{\circ} \mathrm{C}$, using the transmission electron microscopy (TEM) and (non-destructive) x-ray diffraction methods, authors did not observe the crystallization effects. Only smeared halos are presented on the x-ray and electron diffraction patterns. However, the parallel deformation bands of displacements (traces of SPD) are observed. When the degree of deformation increases to $\varepsilon=5$ at room temperature, the formation of heteraxial nanocrystals occurs that is confirmed by the TEM and x-ray data: Figs 1 and 2, respectively. The nanocrystals are distributed randomly in the amorphous matrix. According to the $\mathrm{x}$-ray data, after the SPD, two phases appear in the sample: b.c.c.- $\alpha-F e$ phase and Si-rich $\mathrm{DO}_{3}$ one. The size of nanograins after the strain at

Fig. 2. X-ray diffraction pattern for the strained $\mathrm{Fe}_{81} \mathrm{~B}_{13} \mathrm{Si}_{6}$ alloy, where $\varepsilon=5$, temperatures are $20{ }^{\circ} \mathrm{C}(a)$, $200{ }^{\circ} \mathrm{C}(b), 400{ }^{\circ} \mathrm{C}(c)$, and $500{ }^{\circ} \mathrm{C}$ without deformation (d) [30]

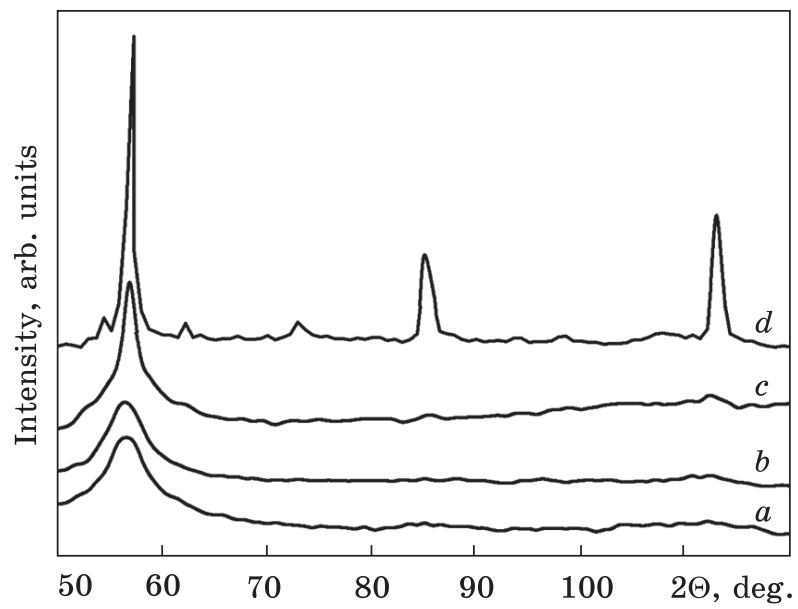




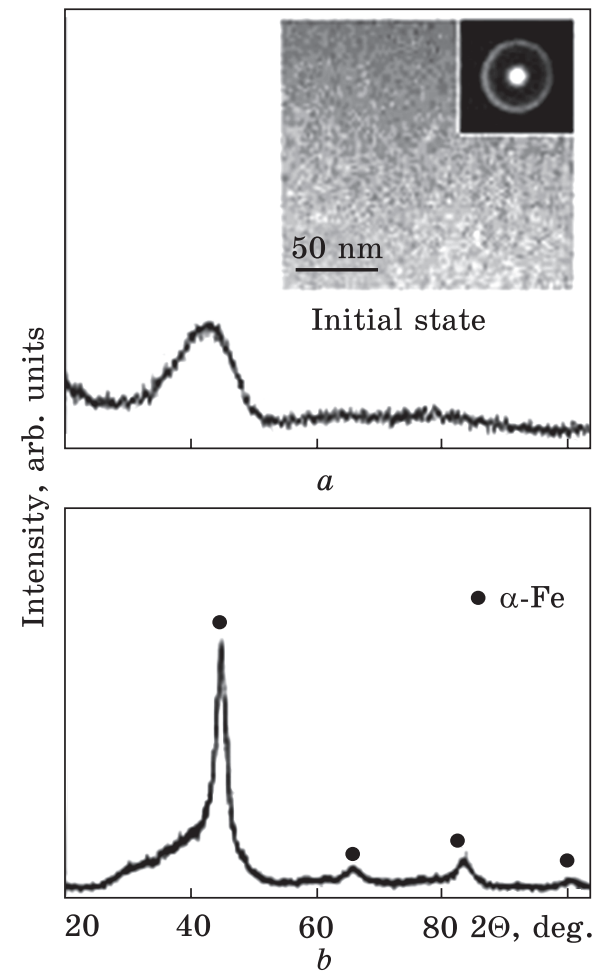

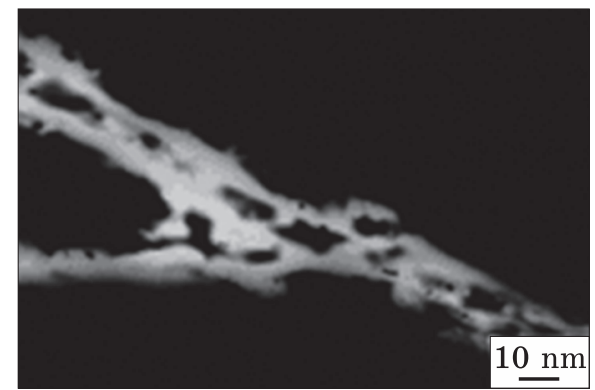

Fig. 4. The TEM image for amorphous $\mathrm{Fe}_{50} \mathrm{Ni}_{33} \mathrm{~B}_{17}(N=1 / 2)$ alloy [29]

Fig. 3. X-ray diffraction pattern for the alloy of the initial sample of the $\mathrm{Fe}_{85} \mathrm{Nd}_{9} \mathrm{~B}_{6}$ alloy $(a)$ and after treatment at room temperature $(b)$. The inset shows the TEM image [31]

room temperature, determined through Scherrer's equation, is of 9-10 $\mathrm{nm}$. At higher temperatures of deformation, the size of nanograins decreases down to $8 \mathrm{~nm}$.

Authors of the paper [31] obtained amorphous ribbons of the $\mathrm{Fe}_{85} \mathrm{Nd}_{9} \mathrm{~B}_{6}$ composition via the spinning method at $40 \mathrm{~m} / \mathrm{s}$ rotational velocity of disk. The samples were deformed at room temperature via the under method of severe torsion under pressure of $6 \mathrm{GPa}$. To study the deformed samples, authors used the x-ray, TEM, and electron-positron annihilation (EPA) methods. The x-ray and TEM data (Fig. 3) confirmed the formation of $\approx 8 \mathrm{~nm} \alpha$-Fe nanocrystals as the strain is applied. The analysis of the EPA lifetime confirmed the formation of vacancy-type defects in the surroundings of Fe atoms, which contribute to the formation of Fe-rich nanocrystals.

As shown in Ref. [29], authors [29] studied amorphous $\mathrm{Fe}_{50} \mathrm{Ni}_{33} \mathrm{~B}_{17}$ ribbon of $30-50 \mu \mathrm{m}$ in thickness obtained by the method of quenching from the melt (spinning) in the open air. The rotation velocity of copper-made quenching disk was 3000-4000 revolutions per minute (rpm). The samples in an initial amorphous state were subjected to the severe torsion under high hydrostatic pressure $(4 \mathrm{GPa})$ at the room and liquidnitrogen $(77 \mathrm{~K})$ temperatures. The total number of revolutions $N$ of 

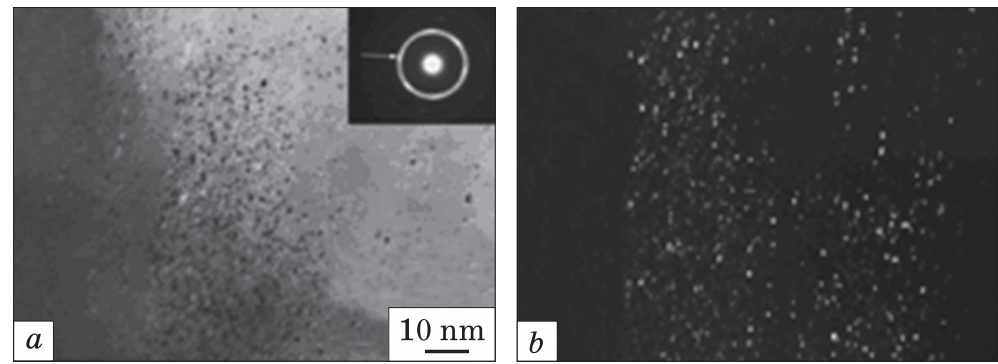

Fig. 5. The TEM-image of the $\mathrm{Fe}_{80} \mathrm{~B}_{20}$ alloy after its deformation at room temperature, where $a$ and $b$ correspond to the bright- and dark-field image, respectively [13]

running anvil (1 $\mathrm{rpm})$ varied sequentially from $1 / 4$ to 9 . According to the TEM data, if $N<1-2$, the deformation is inhomogeneous, which typical for amorphous alloys at relatively low temperatures [32, 33]. The TEM-image in Fig. 4 demonstrates the crystallization effect in the region of strongly localized shear bands for $N=1 / 2$.

The crystallization process at the severe deformation results to the formation (out of a shear band zone) of nanoparticles of the size no more than $20 \mathrm{~nm}$. As authors [29] show, at high deformation degree $(N>1)$, the formation of nanoparticles is not observed in the strongly localized shear bands. In this case, nanoparticles of $10-20 \mathrm{~nm}$ in size are uniformly distributed over the amorphous ribbon volume.

The article [13] devoted to the study of the evolution of the structure of amorphous ribbon of $\mathrm{Fe}_{80} \mathrm{~B}_{20}$ composition at room temperature. The ribbon of $30 \mu \mathrm{m}$ in size was obtained via the method of spinning of melt. To estimate the strain intensity (rate), authors [13] used the expression $\gamma=\phi r / l$, where $\phi$ is the rotation angle (in radians), $r$ is the radius of the sample, and $l$ is the thickness of disk. The value of $\gamma$ parameter was about 300 . Using the plasticity Mises criterion, one can determine the equivalent deformation $\varepsilon$ from the relation $\varepsilon=\gamma \sqrt{3}$.

From the x-ray structural analysis, it was revealed that initial ribbons were amorphous at room temperature as well as after isothermal annealing at $420{ }^{\circ} \mathrm{C}$. After the SPD, the microstructure gets a substantial change. Figure 5 presents TEM image, where an appearance of shear bands of 5-20 nm in width is seen. In the shear bands, there are nanocrystals of $3-15 \mathrm{~nm}$ in size, which appear due to the severe deformation. The matrix regions, which surround the shear bands, remain to be amorphous. X-ray structural analysis indicates that strained samples contain amorphous phase and b.c.c. $\alpha-F e$ nanocrystals with lattice parameter $a=0.286 \mathrm{~nm}$. To calculate an average size of nanocrystals at room temperature after deformation, the Selyakov-Scherrer equation [34] is used: on average, the size is $6 \mathrm{~nm}$. 


\section{Deformation in Ball Mills}

An impact of high-energy strain in the ball mill on the structural transformation in amorphous ribbons of $\mathrm{Fe}_{66} \mathrm{Co}_{18} \mathrm{Si}_{1} \mathrm{~B}_{15}$ and $\mathrm{Fe}_{78} \mathrm{Si}_{9} \mathrm{~B}_{13}$ alloys studied authors of Ref. [16]. Cut into pieces a strip weighing $5 \mathrm{~g}$ was placed in a planetary ball mill system 'Spex 8000 laboratory ball mill'. The treatment was performed with hardened steel balls with a diameter of $5 \mathrm{~mm}$ in an argon atmosphere. Figure 6 shows the x-ray diffraction pattern of the obtained powder, where the structural effects of deformed ribbons are observed.

The first crystallization effect manifests itself after three-hour treatment and is caused by the formation $\alpha-\mathrm{Fe}(\mathrm{Co})$ phase. After 12 hours, the second boride phase $[\mathrm{Fe}(\mathrm{Co})]_{2} \mathrm{~B}$ precipitates. The strain during 24 hours results to the total crystallization of amorphous powder. Some changes associated with severe plastic deformation are also observed (Fig. 7) as a result of using the differential scanning calorimetry (DSC) method to analyse thermal effects.

The first exothermal peak in the vicinity of $441{ }^{\circ} \mathrm{C}$ is due to the precipitation of $\alpha-\mathrm{Fe}(\mathrm{Co})$ phase. The second heat release peak at $521{ }^{\circ} \mathrm{C}$ is attributed to the formation of boride phase. As the duration of the strain increases, the peak broadens and shifts to the low-temperature region.

In order to exclude the thermal effect on the structural changes in the $\mathrm{Fe}_{78} \mathrm{~B}_{13} \mathrm{Si}_{9}$ alloy amorphous ribbon, in Ref. [35], the deformation in the ball mil was performed in an atmosphere of liquid nitrogen. Approximately $20 \mathrm{~g}$ of ribbon was cut into pieces of $14 \times 11 \mathrm{~mm}$. The mass ratio of ribbon/steel balls was 1:100. The drum of the mill of 01-HD UnionProcess type with pieces of ribbon was filled with liquid nitrogen. As a sample for structural analyses, a fine powder (obtained after forty hours' treatment of the original amorphous bands in ball mill) was used.

Figure 8 shows the exothermic peaks of phase crystallization depending on the processing time in ball mill. The observed exothermic effects are due to the decomposition of the amorphous alloy into $\alpha-\mathrm{Fe}(\mathrm{Si})$

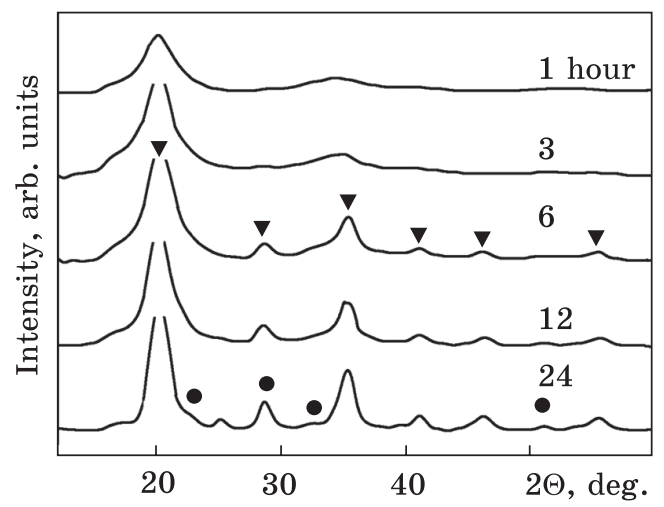
and $\mathrm{Fe}_{2} \mathrm{~B}$ phases at crystallization temperatures of $786 \mathrm{~K}$ and $818 \mathrm{~K}$, respectively. As seen from this figure, the release of exothermic heat during cryogenic treatment decreases with increasing duration of the defor-

Fig. 6. X-ray diffraction pattern of the $\mathrm{Fe}_{66} \mathrm{Co}_{18} \mathrm{Si}_{1} \mathrm{~B}_{15}$ powder alloy after different duration of treatment in the ball mill [16] 

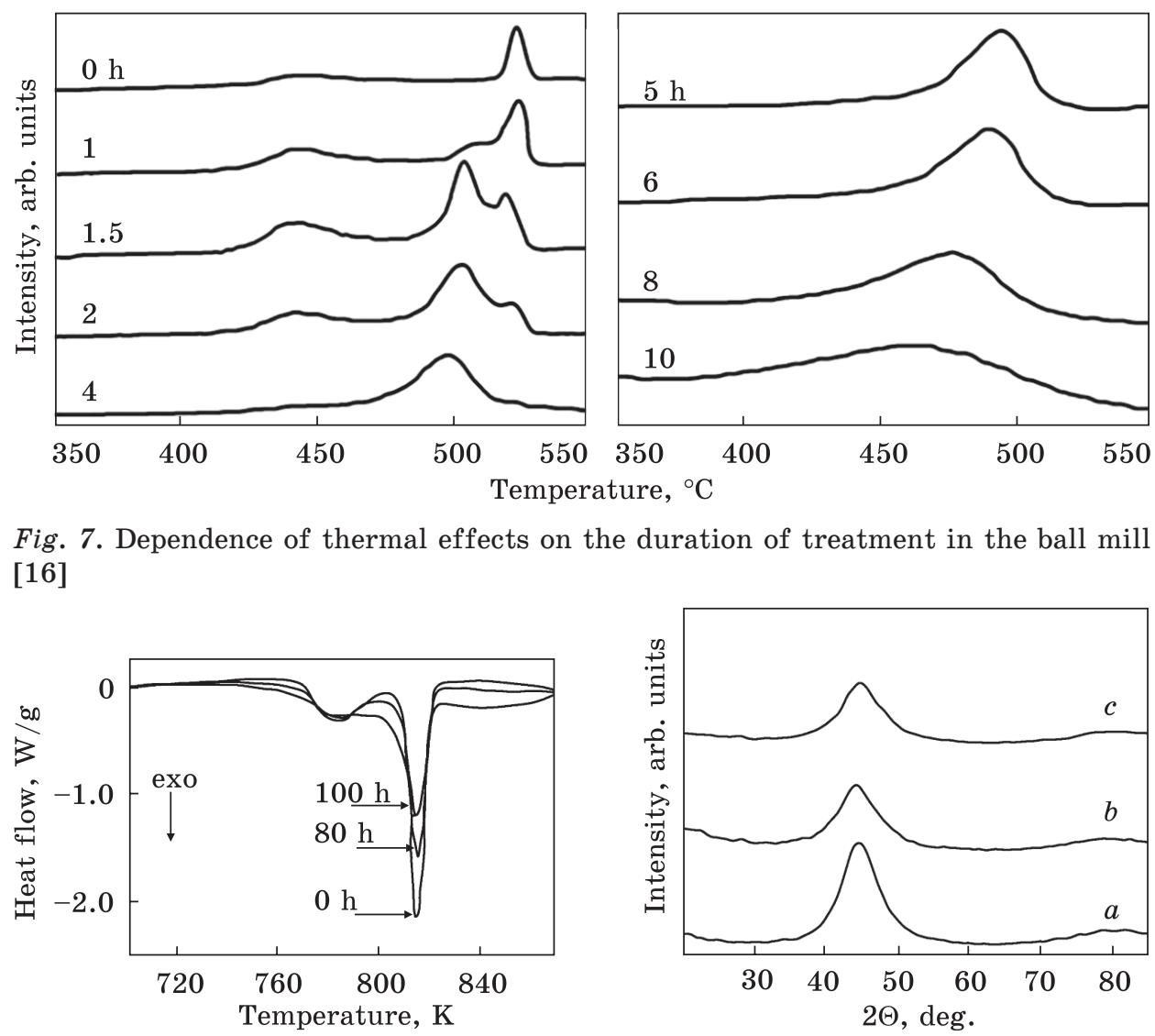

Fig. 7. Dependence of thermal effects on the duration of treatment in the ball mill [16]

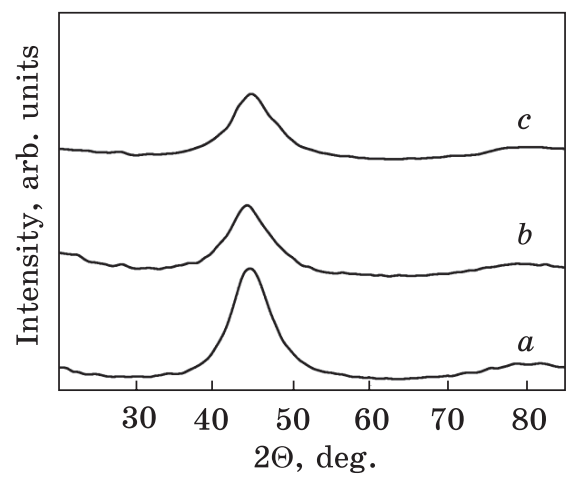

Fig. 8. Exothermic peaks characterizing the crystallization of $\alpha-\mathrm{Fe}(\mathrm{Si})$ and $\mathrm{Fe}_{2} \mathrm{~B}$ in the $\mathrm{Fe}_{78} \mathrm{~B}_{13} \mathrm{Si}_{9}$ alloy at different treatment duration [35]

Fig. 9. X-ray diffraction pattern of the amorphous $\mathrm{Fe}_{80} \mathrm{~B}_{20}$ ribbon after processing in the ball mill for $0 \mathrm{~h}(a), 10 \mathrm{~h}(b)$, and $40 \mathrm{~h}(c)$ [37]

mation effect. This effect is attributed to more intense crystallization of these phases. According to TEM data, the maximum size of nanocrystals is in the range of $6-13 \mathrm{~nm}$, and the minimum size is about $2 \mathrm{~nm}$. Such a treatment significantly improves the magnetic properties of amorphous alloys [36].

The influence of low-energy deformation in ball mill on the crystallization and thermal stability of the amorphous ribbon of $\mathrm{Fe}_{80} \mathrm{~B}_{20}$ composition was studied in Ref. [37]. Low energy was provided by a lower voltage of vibrating mill $(60 \mathrm{~V})$ and a lower mass ratio of balls and pieces of ribbon (4:1). After 40 hours of the deformation, the ribbons did not transform into powder, but only were slightly bent. A typical $\mathrm{x}$-ray diffraction pattern for samples obtained after different processing times is shown in Fig. 9. Blurred (smeared) diffraction peaks char- 


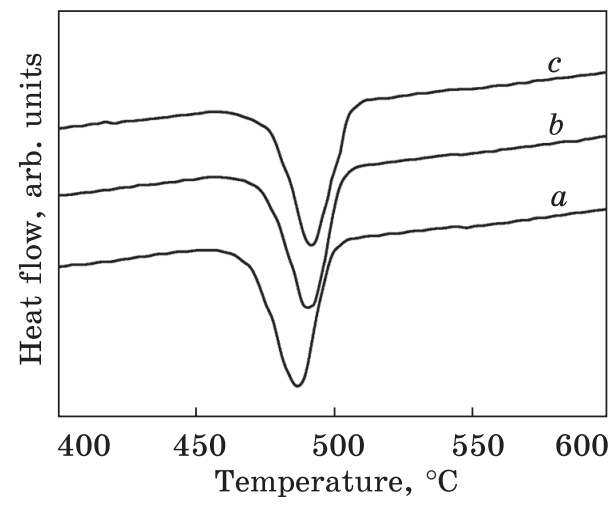

Fig. 10. The differential scanning calorimetry (DSC) spectra for amorphous $\mathrm{Fe}_{80} \mathrm{~B}_{20}$ alloy after different times of deformation in the ball mill [37]

acterise both the initial amorphous phase and the treated samples. The conserved amorphous state after treatment in ball mill was also confirmed by the TEM data.

Figure 10 presents the DSC spectra of the original and treated amorphous alloy for different durations of deformation. As seen from this figure, the exothermic peaks of crystallization of $\alpha-\mathrm{Fe}$ and metastable $\mathrm{Fe}_{3} \mathrm{~B}$ phases are shifted towards higher temperatures with increasing duration of the deformation effect. This indicates an increase of thermal stability after low-energy treatment of $\mathrm{Fe}_{80} \mathrm{~B}_{20}$ alloy in a ball mill. This is due to increase of the activation energy $E_{x}$ of thermal crystallization. The authors [37] explain the effect of increasing the thermal stability of a deformed amorphous alloy by the destruction of probable crystallization centres in amorphous matrix.

The evolution of the microstructure of the amorphous $\mathrm{Fe}_{77.2} \mathrm{Mo}_{0.8} \mathrm{Si}_{9} \mathrm{~B}_{13}$ ribbon with a thickness of $25 \mu \mathrm{m}$ after deformation in high-energy ball mill was investigated in Ref. [17]. The amorphous tape obtained by melt

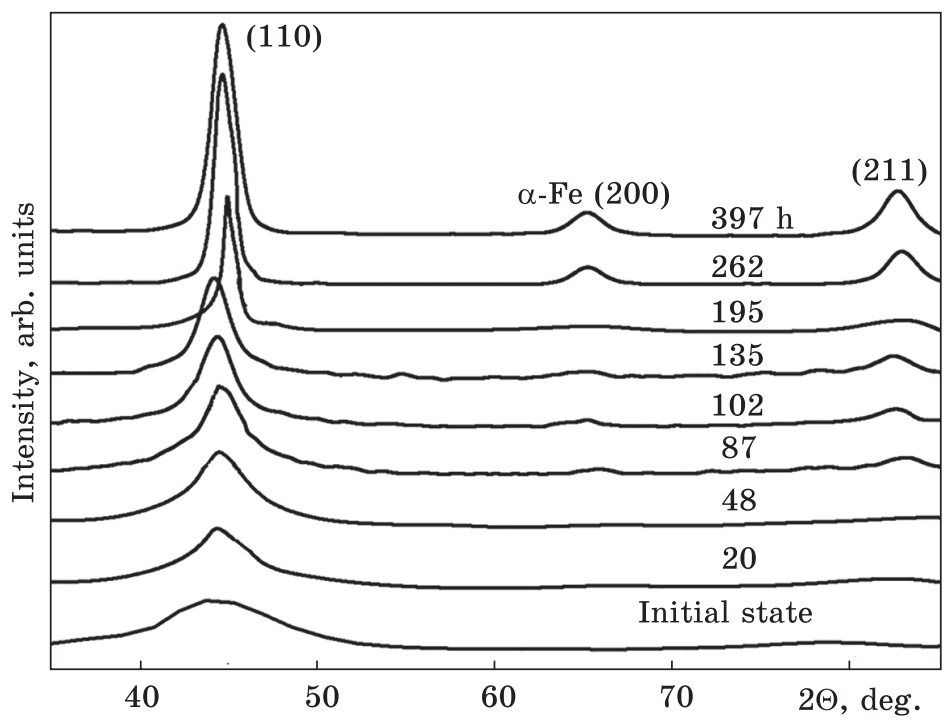

Fig. 11. X-ray diffraction pattern of the $\mathrm{Fe}_{77.2} \mathrm{Mo}_{0.8} \mathrm{Si}_{9} \mathrm{~B}_{13}$ ribbon before and after processing in the ball mill with different duration [17] 

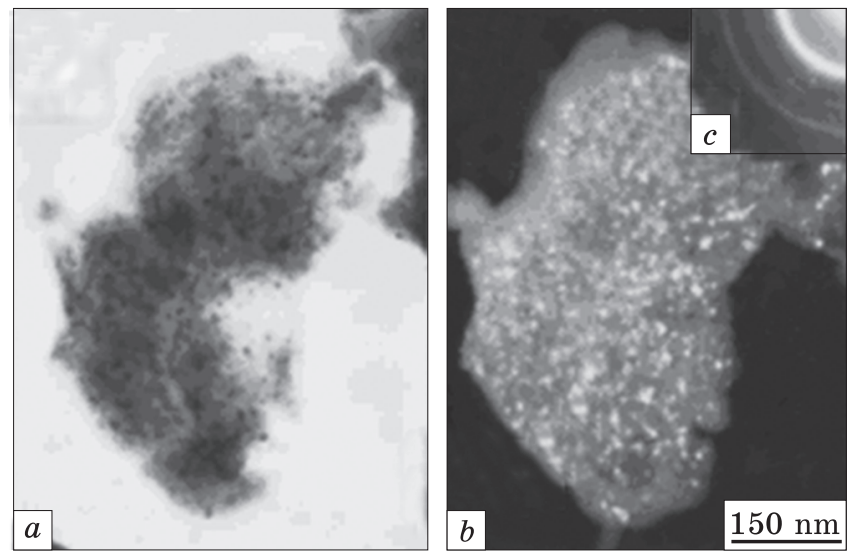

Fig. 12. TEM-image after 135 hours of processing in the ball mill for $\mathrm{Fe}_{77.2} \mathrm{Mo}_{0.8} \mathrm{Si}_{9} \mathrm{~B}_{13}$ alloy: $a$ - bright field image; $b$ - dark-field image; $c$ - electron diffraction pattern [17]

spinning was cut into $55 \mathrm{~mm}$ pieces. Authors [17] used a planetary WL1 -type mill with an operating voltage of $120 \mathrm{~V}$. Processing was performed in an argon atmosphere. The mass ratio of the ball/sample was 40:1.

The change of x-ray diffraction patterns during milling (with different durations) of $\mathrm{Fe}_{77.2} \mathrm{Mo}_{0.8} \mathrm{Si}_{9} \mathrm{~B}_{13}$ ribbon in a ball mill is shown in Fig. 11 . It can be seen that the sample after rapid quenching has a diffuse peak typical for the amorphous phase. After processing, the x-ray patterns change: the diffuse peak for the amorphous phase gradually narrows, and then some crystalline peaks appear. For the sample milled for 20 hours, there are traces of diffraction peaks of the crystalline phase of the b.c.c. $\alpha-F e$ solid solution. Upon further milling, the diffraction maxima are continuously narrowed, but no other crystalline phase is observed. In samples milled for 195 hours, the amorphous phase apparently disappears completely. Further milling leads to more pronounced reflexes for $\alpha-F e$.

The formation of nanocrystalline structures in amorphous $\mathrm{Fe}_{77.2} \mathrm{Mo}_{0.8} \times$ $\times \mathrm{Si}_{9} \mathrm{~B}_{13}$ alloys after ball treatment in ball mills is confirmed by a series of TEM images. As an example, Figure 12 shows the light-field and dark-field image of the milling for 135 hours. Being treated up to 9 hours, the samples retain the original amorphous structure. As the deformation time increases, nanoparticles appear, the size and density of which increase. Some regions of the x-ray diffraction patterns show that the precipitations are b.c.c. Fe with random crystallographic orientations. After milling for 65 hours, the average size of $\alpha$-Fe crystallites (determined by images in a dark field) is in the range from 2 to $10 \mathrm{~nm}$. The sizes of $\alpha-\mathrm{Fe}$ crystallites increase, their quantitative density continuously increases at the subsequent shattering (Fig. 13). 

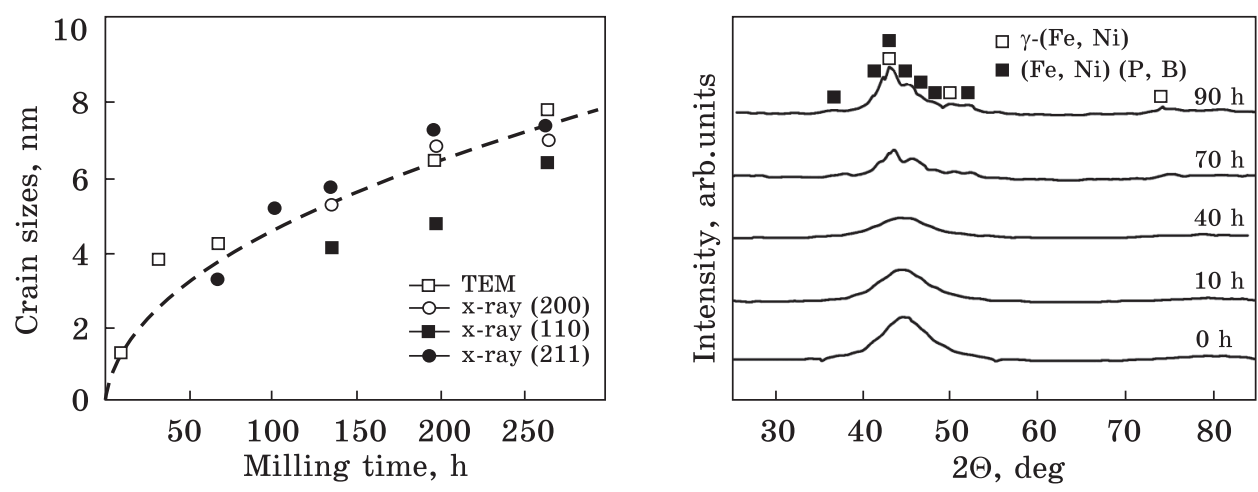

Fig. 13. The size dependence of $\alpha$-Fe nanograins on the time of treatment in the ball mill (according to TEM and x-ray data) [17]

Fig. 14. X-ray diffraction pattern of the amorphous $\mathrm{Fe}_{40} \mathrm{Ni}_{40} \mathrm{P}_{14} \mathrm{~B}_{6}$ alloy for different durations of deformation in the ball mill [18]
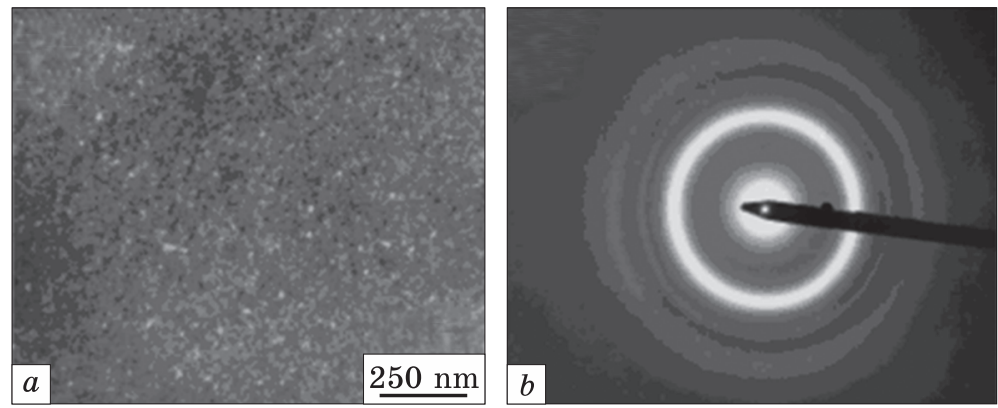

Fig. 15. TEM-image $(a)$ and corresponding diffraction pattern $(b)$ of amorphous $\mathrm{Fe}_{40} \mathrm{Ni}_{40} \mathrm{P}_{14 \mathrm{~B}_{6}}$ alloy processed in the ball mill for $11 \mathrm{~h} \mathrm{[18]}$

The effect of mechanical deformation in high-energy planar ball mill on the structure of an amorphous $\mathrm{Fe}_{40} \mathrm{Ni}_{40} \mathrm{P}_{14} \mathrm{~B}_{6}$ ribbon with a thickness of $20 \mu \mathrm{m}$ obtained by spinning a melt was studied in Ref. [18]. The treatment was carried out in an argon atmosphere. After the strain for 10 hours, the amorphous state persists, and only after 70 hours, reflexes are observed, which can be attributed to a mixture of $\gamma-(\mathrm{Fe}, \mathrm{Ni})$ and $(\mathrm{Fe}, \mathrm{Ni})_{3}(\mathrm{P}, \mathrm{B})$ phases. With a further increase in processing time, there are no changes on the x-ray diffraction patterns. According to TEM, after 11 hours of deformation, nanocrystals with a size of $4 \mathrm{~nm}$ precipitate. After 40 hours of deformation, their dimensions reach 10$20 \mathrm{~nm}$. The maximum duration of deformation (90 hours) in ball mill leads to complete crystallization of the original tape and its transformation into powder. X-ray diffraction patterns of amorphous $\mathrm{Fe}_{40} \mathrm{Ni}_{40} \mathrm{P}_{14} \mathrm{~B}_{6}$ alloy for different duration of deformation, TEM image and the corresponding diffraction pattern for the processed (in ball mill for 11 hours) alloy are shown in Figs. 14 and 15, respectively. 
Fig. 16. X-ray diffraction pattern for initial ribbon $(a), 9 \mathrm{~h}(b), 30 \mathrm{~h}(c), 60 \mathrm{~h}$ $(d)$, and $80 \mathrm{~h}(e)$ of treatment in the ball mill; here, $\bullet-\alpha$-Fe (Mo, $\mathrm{Si}) ;-\mathrm{Fe}_{2} \mathrm{~B}$; and $\mathbf{-}-\mathrm{Fe}-\mathrm{Si}-\mathrm{B}[19]$

The study of the effect of SPD in a ball mill on the structural and phase composition of the amorphous $\left(\mathrm{Fe}_{0.99} \mathrm{Mo}_{0.01}\right)_{78} \mathrm{Si}_{9} \mathrm{~B}_{13}$ ribbon was performed in Ref. [19]. Pieces of amorphous ribbon obtained by

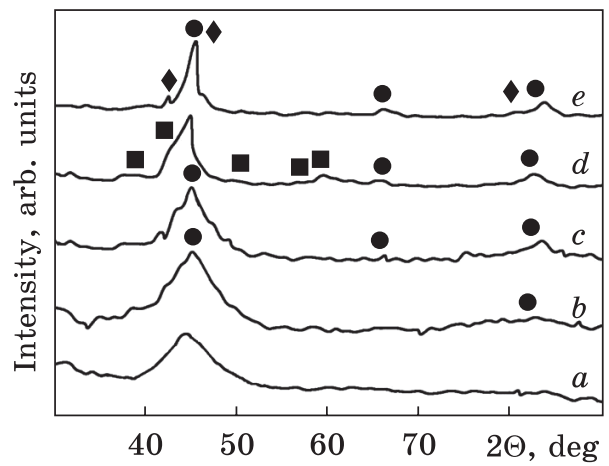
spinning were placed in a vibrating ball mill. The mass ratio of test samples and balls was 1:10. The treatment was carried out in an argon atmosphere. The change of the x-ray diffraction pattern depending on the duration of treatment is shown in Fig. 16.

The diffraction peak of the solid solution of $\alpha$-Fe is detected after 9 hours of treatment. After 30 hours of deformation (Fig. 16, c), this peak becomes more pronounced and shifts toward larger angles. The authors of Ref. [19] attribute the transformation of this peak to the precipitation of the $\alpha$-Fe (Mo, Si) in the amorphous matrix. After 80-hour treatment, the boride $\mathrm{Fe}_{2} \mathrm{~B}$-phase precipitates.

The influence of the neutral and chemically active gaseous medium on the structural changes that occur due to the treatment of the amorphous $\mathrm{Fe}_{78} \mathrm{Si}_{9} \mathrm{~B}_{13}$ alloy in ball mill was studied in Ref. [20]. Pieces of amorphous ribbon with a thickness of $30 \mu \mathrm{m}$ and a size of $5 \times 5 \mathrm{~mm}$ were placed in ball mill. The mass ratio of steel balls and amorphous pieces was $20: 1$. The mill rotated at a velocity of $400 \mathrm{rpm}$. The treatment was performed in argon or air. As a result of processing, the ribbons were

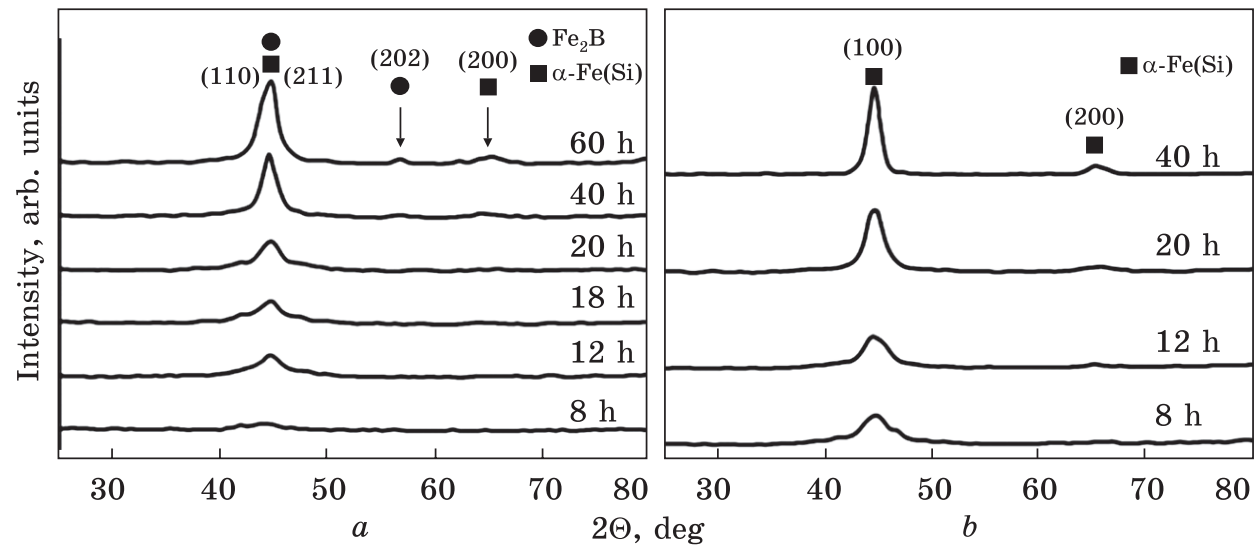

Fig. 17. X-ray diffraction pattern of the $\mathrm{Fe}_{78} \mathrm{Si}_{9} \mathrm{~B}_{13}$ powder alloy for different durations of treatment in the ball mill in argon $(a)$ and in the air $(b)$ [20] 


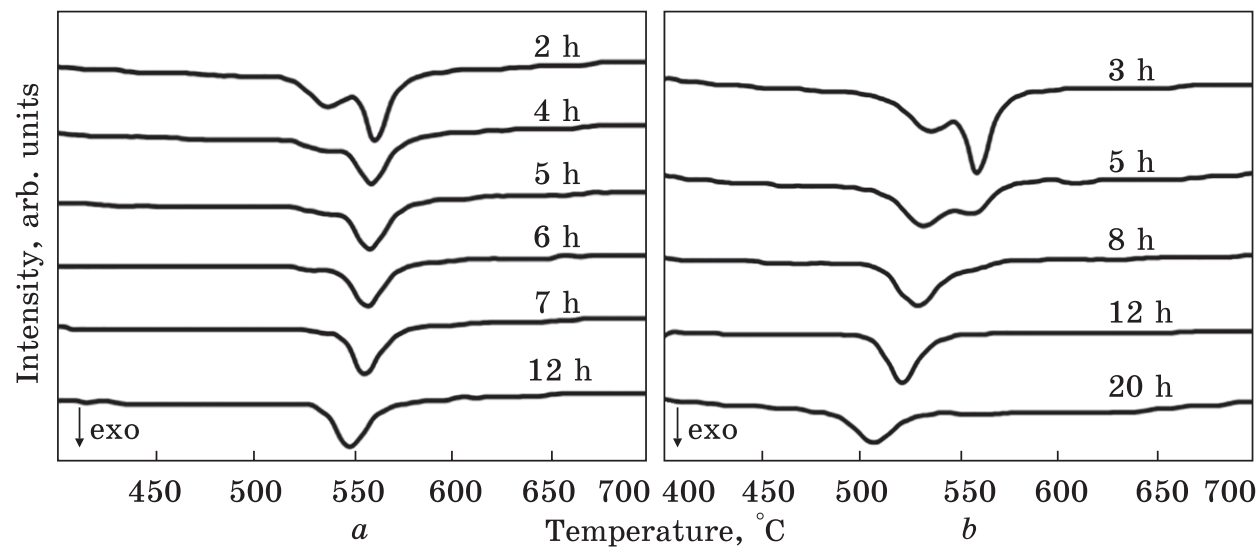

Fig. 18. Thermal effects after the processing of amorphous $\mathrm{Fe}_{78} \mathrm{Si}_{9} \mathrm{~B}_{13}$ samples depending on the treatment duration in the ball mill in argon $(a)$ and air $(b)$ [20]

shattered to a powder state. The treatment in air was performed to establish the effect of oxidation on the structural changes of the alloy during severe plastic deformation.

The x-ray diffraction patterns of $\mathrm{Fe}_{78} \mathrm{Si}_{9} \mathrm{~B}_{13}$ alloy samples deformed in different media are shown in Fig. 17. Processing of $\mathrm{Fe}_{78} \mathrm{Si}_{9} \mathrm{~B}_{13}$ alloy in argon (Fig. 17, $a$ ) for up to 8 hours takes place with conservation of the initial amorphous state of the samples. After 12 hours of severe deformation, the reflex (110) from the b.c.c. $\alpha-\mathrm{Fe}(\mathrm{Si})$ phase appears on the $\mathrm{x}$-ray diffraction patterns. As the processing time increases, the magnitude of this reflex increases, indicating a decrease in the volume of the amorphous phase. After 24 hours of processing, the reflex (200) appears on the $\mathrm{x}$-ray diffraction patterns, which is also attributed to the $\alpha$-Fe (Si) phase. Severe deformation for 40 hours leads to the precipitation of a new phase - tetragonal $\mathrm{Fe}_{2} \mathrm{~B}$ boride with a maximum (202). The intensity of this peak increases considerably after 60-hours' treatment. Thus, the severe deformation in the neutral atmosphere leads to eutectic crystallization with the formation of $\alpha-\mathrm{Fe}(\mathrm{Si})$ and $\mathrm{Fe}_{2} \mathrm{~B}$ phases. Such crystallization products are identical to those obtained in the case of thermal exposure.

According to TEM data, the size of the $\alpha-\mathrm{Fe}(\mathrm{Si})$ phase crystallites is several tens of nanometers for both media. At the deformation of $\mathrm{Fe}_{78} \mathrm{Si}_{9} \mathrm{~B}_{13}$ alloy in a ball mill in air for 8 hours, the precipitation of the $\alpha-\mathrm{Fe}(\mathrm{Si})$ phase is also observed. The intensities of the maxima (110) and (200) that belong to it also increase with increasing duration of deformation. However, in contrast to the treatment in argon, after 40 hours, amorphous $\mathrm{Fe}_{78} \mathrm{Si}_{9} \mathrm{~B}_{13}$ alloy completely crystallizes with the formation of the $\alpha-F e(\mathrm{Si})$ phase without the precipitation of borides. In this case, the difference between the final phase composition of the deformed samples 

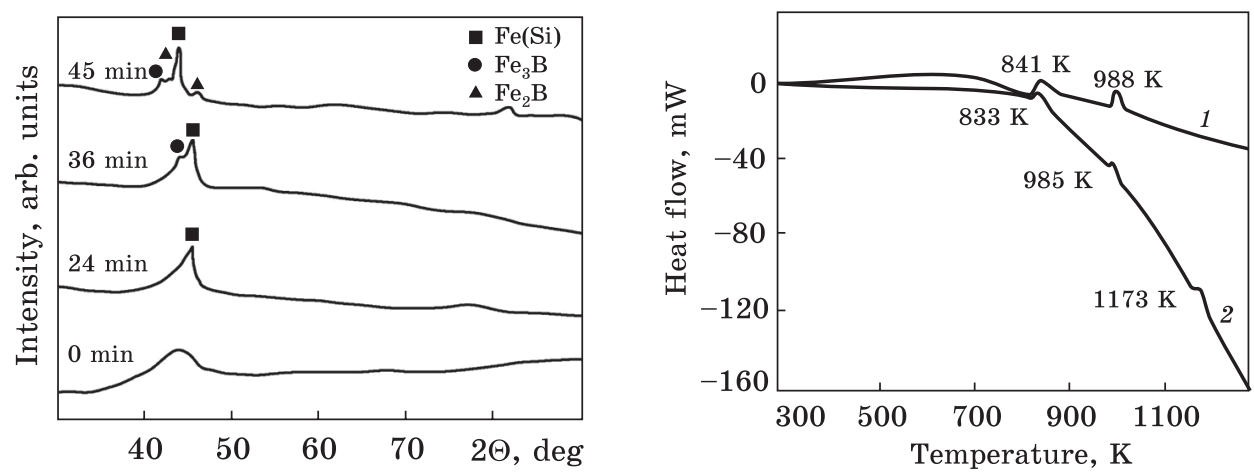

Fig. 19. X-ray diffraction pattern for different times of the processing of amorphous $\mathrm{Fe}_{73.5} \mathrm{Si}_{13.5} \mathrm{~B}_{9} \mathrm{Nb}_{3} \mathrm{Cu}_{1}$ ribbon in the ball mill for [21]

Fig. 20. The DSC data for amorphous $\mathrm{Fe}_{73.5} \mathrm{Si}_{13.5} \mathrm{~B}_{9} \mathrm{Nb}_{3} \mathrm{Cu}_{1}$ ribbon in the initial state (1) and after processing in ball mil for 45 min (2) [21]

and the thermally crystallized ones is due to the introduction of oxygen into the deformed powders. According to TEM, the size of the $\alpha-\mathrm{Fe}(\mathrm{Si})$ phase crystallites is several tens of nanometers for both media.

Figure 18 shows the results of DSC analysis for different processing times of the $\mathrm{Fe}_{78} \mathrm{Si}_{9} \mathrm{~B}_{13}$ alloy in argon and in air. At the initial stage of milling (up to 6 hours) in an argon atmosphere, two exothermic peaks are observed (Fig. 18, $a$ ) in the DSC spectra. The intensity of first peak decreases with increasing milling time and disappears after 7 hours of deformation. With a further increase of the processing time, only one peak remains on the DSC spectra. Figure 18, $b$ shows the DSC spectra for different processing times of the amorphous $\mathrm{Fe}_{78} \mathrm{Si}_{9} \mathrm{~B}_{13}$ alloy in air. As can be seen from the figure, the DSC patterns contain two exothermic peaks after milling the samples for up to 8 hours; the intensity of first (second) peak gradually increases (decreases) and then disappears with increasing grinding time. In the case of the SPD for a time exceeding 12 hours, there is only one exothermic peak on the DSC spectra.

In Reference [21], the kinetics of mechanoactivated crystallization of the amorphous ribbon of the $\mathrm{Fe}_{73.5} \mathrm{Si}_{13.5} \mathrm{~B}_{9} \mathrm{Nb}_{3} \mathrm{Cu}_{1}$ composition (FINEMET) during processing in a ball mill was investigated. The ribbon was obtained by spinning the melt by rotating a copper disk at a velocity of 38 $\mathrm{m} / \mathrm{s}$. The treatment was performed in a high-energy vibrating mill in an argon atmosphere at a velocity of $750 \mathrm{rpm}$ and a mass ratio of balls/ sample of 24:1. The vibration of the mill was carried out in three directions $(x, y, z)$. X-ray diffraction patterns of the original and treated ribbons are shown in Fig. 19. After 24 minutes of processing, one can see on the patterns the appearance of reflexes from the $\alpha-\mathrm{Fe}(\mathrm{Si})$ phase in the superposition with smeared reflexes from the amorphous alloy. After 36-minutes' deformation, the reflexes appear from $\mathrm{Fe}_{3} \mathrm{~B}$ boride. 
More intensive (severe) treatment leads to the formation of the $\alpha-\mathrm{Fe}(\mathrm{Si})$ $+\mathrm{Fe}_{3} \mathrm{~B}$ phase mixture.

Figure 20 shows the DSC curves for the alloy $\mathrm{Fe}_{73.5} \mathrm{Si}_{13.5} \mathrm{~B}_{9} \mathrm{Nb}_{3} \mathrm{Cu}_{1}$ in the initial state and after deformation in ball mill for $45 \mathrm{~min}$. For the ribbon in the initial amorphous state, the DSC curves contain two exothermic peaks. The first low-temperature peak is due to the formation of the $\alpha-\mathrm{Fe}(\mathrm{Si})$ phase, while the second peak authors [21] attribute to the precipitation of the $\mathrm{Fe}_{23} \mathrm{~B}_{6}$ and $\mathrm{Fe}_{3} \mathrm{~B}$ boride phases. In the DSC curves of deformed samples, there are three exothermic maxima at $833 \mathrm{~K}\left(560{ }^{\circ} \mathrm{C}\right)$, $985 \mathrm{~K}\left(712{ }^{\circ} \mathrm{C}\right)$, and $1173 \mathrm{~K}\left(900{ }^{\circ} \mathrm{C}\right)$ temperatures caused by the precipitation of the $\alpha-\mathrm{Fe}(\mathrm{Si}), \mathrm{Fe}_{3} \mathrm{~B}$, and $\mathrm{Fe}_{2} \mathrm{~B}$ phases, respectively. There is also a slight shift of both peaks towards lower temperatures. The area under the exothermic peaks, which reflect the change in the enthalpy of crystallization and the degree of amorphousness, also changes. For example, the enthalpy of crystallization as a result of the deformation effect varies from 57.54 to $45.36 \mathrm{~J} \cdot \mathrm{g}^{-1}$ and from 57.54 to $45.36 \mathrm{~J} \cdot \mathrm{g}^{-1}$ for $\alpha-\mathrm{Fe}(\mathrm{Si})$ and $\mathrm{Fe}_{23} \mathrm{~B}_{6} / \mathrm{Fe}_{3} \mathrm{~B}$, respectively. Enthalpy of crystallization of the strained $\mathrm{Fe}_{2} \mathrm{~B}$ boride is $32.42 \mathrm{~J} \cdot \mathrm{g}^{-1}$. Crystallization of the $\mathrm{Fe}_{2} \mathrm{~B}$ phase and reduction of enthalpy of crystallization of $\mathrm{Fe}_{23} \mathrm{~B}_{6}$ boride after $45 \mathrm{mi}$ nutes of treatment in ball mill is caused by the decomposition of metastable $\mathrm{Fe}_{23} \mathrm{~B}_{6}$ phase onto tetragonal $\mathrm{Fe}_{2} \mathrm{~B}$ and $\mathrm{Fe}_{3} \mathrm{~B}$ borides as well as $\alpha-\mathrm{Fe}$ according to the following reaction: $\mathrm{Fe}_{23} \mathrm{~B}_{6} \rightarrow \alpha-\mathrm{Fe}+\mathrm{Fe}_{3} \mathrm{~B}+\mathrm{Fe}_{2} \mathrm{~B}$.

According to the TEM data, after treatment of the amorphous $\mathrm{Fe}_{73.5} \mathrm{Si}_{13.5} \mathrm{~B}_{9} \mathrm{Nb}_{3} \mathrm{Cu}_{1}$ ribbon for 45 minutes, the amorphous phase almost completely disappears, and the obtained powders have a nanocrystalline structure with a grain size of $\approx 9 \mathrm{~nm}$. Interestingly to note that the crystals formed as a result of deformation nanocrystallization are smaller than those ones obtained by means of the traditional annealing.

\section{High-Frequency Shock Treatment (Impact Peening)}

In the paper [38], authors firstly investigated the effect of deformation nanocrystallization as a result of high-frequency shock treatment (impact peening [39]). Such a deformation treatment belongs to one of the methods of metal surfaces' SPD widely used for increasing their strength and durability [5, 39]. The authors of Ref. [38] investigated the structural changes in the amorphous ribbon of $\mathrm{Fe}_{73.6} \mathrm{Si}_{15.8} \mathrm{~B}_{7.2} \mathrm{Cu}_{1.0} \mathrm{Nb}_{2.4}$ alloy with a thickness of $25 \mu \mathrm{m}$ obtained by the melt spinning method. According to the results of structural studies, the obtained ribbons after a long exposure to air remained amorphous ('x-ray amorphous'). Only wide diffuse maxima, which are typical for amorphous alloys, were observed on the corresponding diffractograms. The 'free' surface of the ribbon, which did not come into contact with the cooling disk, was subjected to the high-frequency shock treatment (impact peening [39]). 

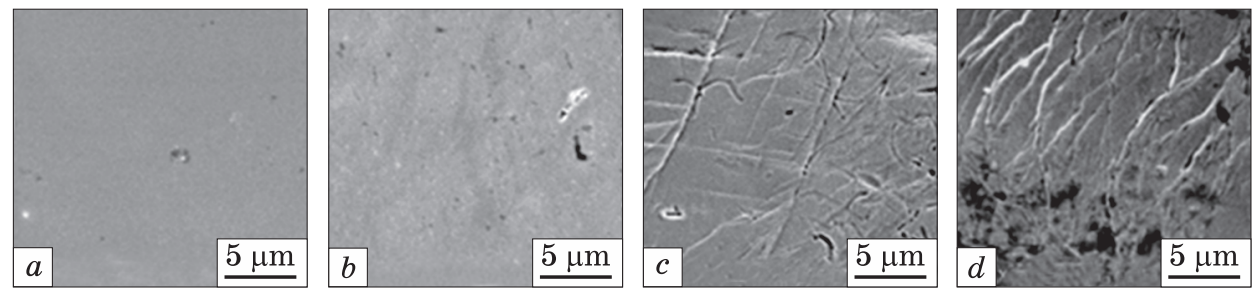

Fig. 21. The morphology $(\times 5000)$ of the amorphous $\mathrm{Fe}_{73.6} \mathrm{Si}_{15.8} \mathrm{~B}_{7.2} \mathrm{Cu}_{1.0} \mathrm{Nb}_{2.4}$ ribbon surface in the initial state $(a)$, and after $10 \mathrm{~s}(b), 30 \mathrm{~s}(c), 60 \mathrm{~s}(d)$ of the high-frequency shock treatment [38]
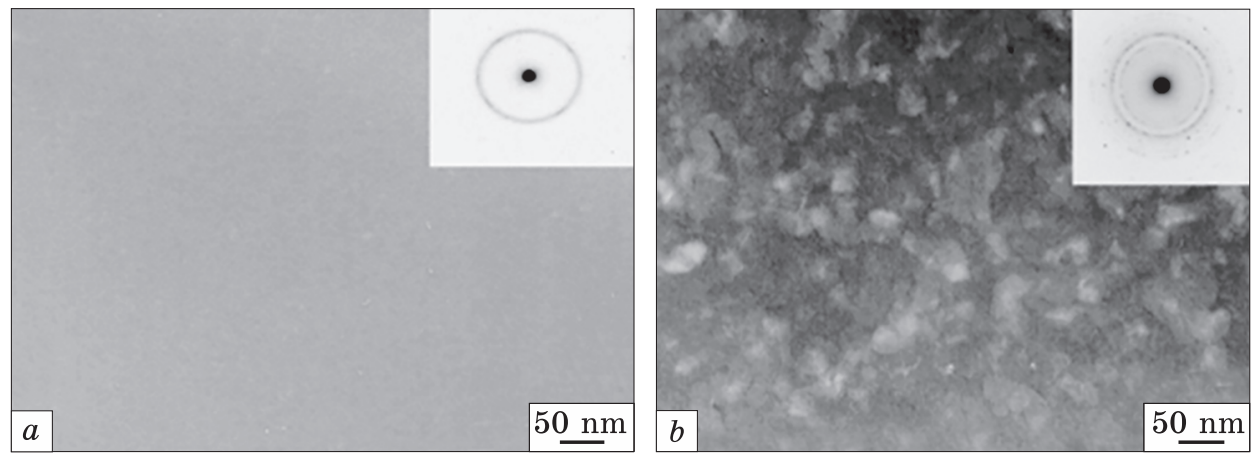

Fig. 22. The TEM image of the same sample of amorphous ribbon as in the previous figure, where $a$ corresponds to the initial state and $b-$ after $60 \mathrm{~s}$ of the high-frequency shock treatment $(b)$ [38]

Processing was performed at room temperature using an ultrasonic generator UZG-300, which powers a concentrator operating at a frequency of $21 \mathrm{kHz}$ [39]. The impact pin with a diameter of $5 \mathrm{~mm}$ and a length of $23 \mathrm{~mm}$, made of hardened steel SHH15, performs forced high-frequency oscillations with a frequency of $1-2 \mathrm{kHz}$ and amplitude of $20 \mu \mathrm{m}$. The duration of the treatment varied in the range from 10 to $60 \mathrm{~s}$.

The scanning electron microscope (SEM) image of the $\mathrm{Fe}_{73.6} \mathrm{Si}_{15.8} \times$ $\times \mathrm{B}_{7.2} \mathrm{Cu}_{1.0} \mathrm{Nb}_{2.4}$ alloy surface morphology in the initial state and processed during different times are depicted in Fig. 21. On the ribbon surface before the treatment (Fig. 21,a), the morphological inhomogeneity there was not revealed. The first stage of the plastic deformation, when the slight structural elements are already observed, manifests itself after $10 \mathrm{~s}$ treatment. Most probably, the polishing (buffing) processes cause these changes. Longer processing (30 s) leads to a noticeable transformation of the surface morphology due to the formation of mechanical defects during the horizontal sliding of the pin and the beginning of the occurrence of shear bands (Fig. 21, c). After 60-seconds' treatment (Fig. 21, d), the system of parallel arcuate shift bands is clearly observable on the surface of the ribbon. Between the coarser shear bands, the 
fine shifts are detected, which apparently characterize different shear systems in the amorphous ribbon. Shear zones have an elongated shape and wavy character; their thickness is about $50-100 \mathrm{~nm}$, and the width reaches the values of several micrometers. At the treatment more than $60 \mathrm{~s}$, the sample is completely destroyed without the effect of plastic thinning of the ribbon due to the formation of a large number of brittle microcracks. This fact confirms the fragile nature of the destruction of amorphous ribbon during the high-frequency shock treatment, which is characteristic of other types of strain destruction of amorphous materials.

The TEM-based results (Fig. 22, a) of the original amorphous $\mathrm{Fe}_{73.6} \mathrm{Si}_{15.8} \mathrm{~B}_{7.2} \mathrm{Cu}_{1.0} \mathrm{Nb}_{2.4}$ ribbon confirmed the absence of special structural details. There were no detected a diffraction contrast as well. Only diffuse halos were observed on the electron-diffraction pattern as well as on the x-ray diffraction pattern. A similar pattern is fixed after processing for $10 \mathrm{~s}$ and $30 \mathrm{~s}$. Significant structural changes occur only after increasing the duration of the impact up to $60 \mathrm{~s}$ (Fig. 22, b). In this case, the main deformation-induced modification of the structure is attributed to the formation of a large number of homogeneously distributed nanoparticles, the sizes of which are in the range of 5-25 nm. The presence of nanocrystals (inset in Fig. 22, b) is confirmed by the presence of point reflexes on the microdiffractogram. According to the structural analysis results, it was found that the formed nanoparticles are b.c.c. $\alpha-\mathrm{Fe}(\mathrm{Si})$ phase, which are also formed during thermally induced crystallization of the alloy at issue.

\section{Mechanism of Deformation Nanocrystallization}

A large number of scientific works are devoted to the mechanism of deformation of amorphous alloys under normal and intensive (severe) regimes. Let us consider the main features of plastic deformation of such materials, important for understanding the nature of deformationinduced nanocrystallization. Numerous studies show that the most stable state after the SPD is an amorphous-nanocrystalline structure with nanocrystal sizes not exceeding $10-20 \mathrm{~nm}$. A characteristic feature of such amorphous-nanocrystalline alloys is, first of all, that the structural (phase) components of such a system differ significantly in the structure of the atomic structure: the matrix is disordered at the atomic level and the crystalline inclusions are completely ordered. As assumed, the appearance of a high-modulus crystalline phase in the structure of alloys during nanocrystallization creates conditions for a significant increase in their strength [40-43].

Depending on the deformation and temperature regimes, the amorphous alloys exhibit either a 'heterogeneous' plastic flow (yielding) lo- 
calized in shear bands or a 'homogeneous' flow (yielding), which is realized without any indications of deformation localization [44-50].

The inhomogeneous flow occurs at temperatures below the crystallization temperature of the amorphous alloy and high applied strain stresses. This type of deformation is characterized by almost complete absence of deformation hardening, peculiar to the deformation of crystalline metallic materials, and is localized in thin $(10-40 \mathrm{~nm})$ discrete shear bands. However, the rest of the material remains unstrained. This explains the small elongation at stretching (1-2\%). On the surface of the destruction of amorphous alloy samples, we can usually observe 'river-type' pattern (sometimes called 'vein structure'). Thus, the mechanism of deformation of amorphous alloys at low temperatures is the formation and propagation of shear bands. With homogeneous plastic deformation, which occurs at temperatures above the temperature of thermostimulated crystallization, the amorphous alloy undergoes plastic form change throughout the volume. In this case, the deformed sample undergoes a homogeneous deformation.

There are two theoretical models of the mechanism of inhomogeneous deformation of metal amorphous alloys, proposed by Spaepen [51] and Argon [52] for metallic glasses. According to theoretical propositions of the first model, the deformation of the amorphous alloy increases such a structural characteristic as the free volume, which leads to a local decrease in the viscosity and density of the metal in the shear bands. As a result, there is an uncontrolled passing the shear band and, as a consequence, the fragile destruction of the amorphous sample. The second model explains the significant decrease in the viscosity of the deformed material by an increase in the temperature shift bands up to the melting point.

Thus, the most important features of the deformation of amorphous metal alloys are, firstly, the lack of deformation hardening typical of crystalline materials and, secondly, that plastic deformation occurs in narrowly localized shear bands $(10-40 \mathrm{~nm})$. The almost complete absence of deformation outside these bands explains the reason for the low values of macroscopic plasticity, in particular, during stretching.

In a large number of research works, it has been established that the shear bands in amorphous alloys strongly affect the formation of the atomic structure of alloys of different compositions, as well as the physical and mechanical characteristics. The severe plastic deformation in various ways allows controlling the number and structure of shear bands. It is also noted that using the methods of preliminary plastic deformation, even the plasticity of amorphous alloys can be increased [45-47].

Deformation shear bands in amorphous alloys are the object of many years of close attention of researchers due to their important role in the mechanism of deformation nanocrystallization. There are several approa- 
ches to explaining the nature of this phenomenon, which is of both fundamental and practical interest.

In the earlier studies [53-56], authors firstly described the appearance of the SPD-induced crystalline phases in amorphous metal alloys with an atomic short-range order only (which is always inherent even in disordered solid solutions; see, e.g., articles [57-61] and references therein). Nevertheless, the question of the current mechanism of nanocrystallization still remains controversial. However, taking into account the importance of obtaining new functional properties of AMA by severe deformation, let us consider existing approaches describing the mechanism of deformation nanocrystallization in such materials.

As follows from the analysis of literature data, an important feature of the structural and phase changes at the SPD of amorphous alloys is the effect of deformation nanocrystallization not only at room temperature but at cryogenic ones as well. This effect is reliably established for various methods of severe deformation of amorphous Fe-, Co-, Ni-, $\mathrm{Al}$-, and Zr-based alloys. The deformation-induced crystallization occurs both in rapid-quenched thin ribbons and in bulk samples. The formation of nanoparticles was detected by such methods of deformation effects as torsion under pressure, machining (processing) in ball mills, repeated rolling, bending, diamond pyramid indentation, and high-frequency shock treatment (impact peening).

Despite the fact that currently still there is no consensus on some features of the nature of the deformation nanocrystallization of amorphous alloys at the SPD, a common opinion has been formed about the important role of shear-deformation bands ('strain localization') in the nucleation, growth and distribution of formed nanocrystals. It is known that such a real mechanism of dissipation of the supplied deformation energy as plastic deformation by the motion of dislocations inherent in polycrystalline metals is excluded in the case of deformation of amorphous metal alloys, in which there is no long-range order in the atomic structure [26, 27, 45-47,62-64].

It is shown that in the conditions of very large deformations at the room and lower temperatures, the processes of nanocrystallization are connected with the nature of the plastic flow. Just the localized shear bands are the areas in which anomalous effects of crystallization of amorphous alloys are observed. As the degree of deformation increases, the nature of the plastic flow changes from heterogeneous to homogeneous. In this case, 10-20 nm nanoparticles of the crystalline phase are randomly distributed over the entire volume of the sample [32, 65].

An important issue for a deeper understanding of the physical nature of deformation nanocrystallization is the effect of the heating effect in the area of shear-deformation bands as the main location of nanocrystal separation. There are questionable and even contradictory views 
on this problem. In some early works [51, 52, 66-68], it was noted that the nucleation of ordered nanoparticles is caused by adiabatic heat release in shear deformation bands. By the opinion of authors in Ref. [69], in the process of shear band propagation, the temperature in the amorphous matrix becomes higher and eventually reaches the crystallization temperature, at which nanoparticles are formed. The formed nanocrystal is not capable of dislocation plastic flow [70]. The role of thermal energy release and spontaneous temperature rise is also noted in Refs. [67, 69, $71,72]$. However, these and other authors [73] believe that the cause of crystallization is both a local temperature increase and the presence of significant local stresses. The latter factor may be decisive, e.g., in the case of SPD at cryogenic temperatures. According to the estimations [41], the temperature in the shear-deformation bands can reach $2500 \mathrm{~K}$.

There is also an idea in the literature that the consequence of a local temperature increase in the region of shear-deformation bands is the diffusion mass transfer of amorphous alloy components in the nanoscale region. Using the temperature dependence of the diffusion coefficient $[74,75]$, the authors [13] estimated the temperature in the shear band: $400-450{ }^{\circ} \mathrm{C}$. This temperature value is close to the crystallization temperature of the amorphous $\mathrm{Fe}_{80} \mathrm{~B}_{20}$ alloy, i.e., the formation of nanocrystals in the amorphous phase by the diffusion mechanism of nucleation and growth is possible. Estimating the effect of mass transfer, mentioned authors considered diffusion in the amorphous matrix of the largest atom, i.e., $\mathrm{Fe}$, as the limiting stage of nanocrystal growth. The calculated diffusion coefficient $D$ value at room temperature is $\approx 10^{-19} \mathrm{~m}^{2} \cdot \mathrm{s}^{-1}$. In Reference [76], it was suggested that the chemical segregation of boron atoms is a necessary condition for the crystallization of $\alpha$-Fe $(\mathrm{Si})$ in the case of SPD of amorphous alloy of the $\mathrm{Fe}-\mathrm{B}-\mathrm{Si}$ system. In this case, only a short-range diffusion is required, since the average crystal size is approximately $2 \mathrm{~nm}$ that corresponds to an average diffusion path of less than $1 \mathrm{~nm}$. This high mobility at room temperature can be explained as follows. With intense deformation due to the migration of atoms within the shear-deformation bands, the probability of stable clusters increases close to them. As known, the deformation of the amorphous alloy shows the expansion of the material due to the formation of shear-strain bands. During the deformation, the free volume increases at first, and then with the increase of the degree of deformation and the beginning of nanocrystallization it decreases, which leads to the annihilation of the free volume by the growth of nanocrystals. Thus, due to shear stresses and increasing the amount of free volume, the diffusion mobility of atoms increases, which promotes the formation of crystals during the SPD process. The estimations have shown that the formation of excess volume in the process of plastic flow can lead to an increase in the diffusion coefficient in the shear zones by 4-6 orders of magnitude 
[77]. In contrast to the mechanism of thermal activation of structural transformations, at the SPD, there is an argument that this process is athermal, and a high local temperature rise at the SPD is not the driving force of crystallization [12, 42]. This conclusion can be confirmed by experiments with nanoindentation, in which it is difficult to expect intense heating in the shear-deformation bands, but where the deformation nanocrystals are also detected [78].

\section{Conclusion}

Based on the review and analysis of the literature data, we conclude that one of the most effective methods of transforming the structure and properties of amorphous iron-based alloys is the severe plastic deformation. This method of material processing allows achieving significant morphological changes not only on the surface but also in the volume of the sample without destroying it. From a practical point of view, an interesting effect of the severe plastic deformation is the nanocrystallization of amorphous alloys at relatively low (and even cryogenic) temperatures, which has a beneficial effect on the strength and magnetic characteristics of the processed materials. The mechanism of nanocrystallization of amorphous alloys, which were subjected to different types of severe plastic deformation, consists in the emergence of sheardeformation bands, in which, due to the increase in free volume, the diffusion mobility of atoms, which promotes the formation of crystals in the amorphous matrix, increases by 4-6 orders of magnitude.

Acknowledgements. The work contains results of the study carried out within the framework of the project on the state budget research 'Scientific Fundamentals of the Mechanochemical Ultrasonic Synthesis of the Abrasion Resistant Coatings on the Aviation Engineering Alloys with Increasing Military Capabilities' (КПКВК 2201330) according the agreement between the Ministry of Education and Science of Ukraine and National Technical University of Ukraine 'Igor Sikorsky Kyiv Polytechnic Institute (state registration number 0118U000220) and scientific research 'Micro- and Nanocrystalline States in New Precision Eutectic Type Alloys' (КПКВК 6541230) according to the agreement between the National Academy of Sciences of Ukraine and G.V. Kurdyumov Institute for Metal Physics of the N.A.S. of Ukraine (state registration number 0120U000133).

\section{REFERENCES}

1. G. Gleiter, Acta Mater., 48, No. 1: 1 (2000). https://doi.org/10.1016/S1359-6454(99)00285-2

2. R.Z. Valiev and I.V. Aleksandrov, Nanostrukturnyye Materialy, Poluchennyye Intensivnoy Plasticheskoy Deformatsiey [Nanostructural Materials Obtained by the Severe Plastic Deformation] (Moscow: LOGOS: 2000) (in Russian). 
3. S.I. Sydorenko, Yu.M. Makohon, and S.M. Voloshko, Materialoznavstvo Tonkoplivkovykh Nanostruktur. Dyfuziya i Reaktsiyi [Materials Science of Thin Film Nanostructures. Diffusion and Reactions] (Kyiv: Naukova Dumka: 2000) (in Ukrainian).

4. A.P. Shpak, Yu.A. Kunitskiy, and V.I. Lysov, Klasternyye i Nanostrukturnyye Materialy [Cluster and Nanostructural Materials] (Kyiv: Akademperiodyka: 2002) (in Russian).

5. K.S. Kumar, H. Van Swygenhoven, and S. Suresh, Acta Mater., 51, No. 19: 5743 (2003).

https://doi.org/10.1016/j.actamat.2003.08.032

6. V.V. Gors'ky, O.M. Grypachevs'ky, V.V. Tykhonovych, and V.M. Uvarov, Usp. Fiz. Met., 4, No. 4: 271 (2003) (in Russian). https://doi.org/10.15407/ufm.04.04.271

7. A.M. Glezer, Izvestiya RAN. Ser. Fizicheskaya, 71: 1767 (2007) (in Russian).

8. M.O. Vasiliev, G.I. Prokopenko, and V.S. Filatova, Usp. Fiz. Met., 5, No. 3: 345 (2004) (in Russian). https://doi.org/10.15407/ufm.05.03.345

9. Y. Yoshizawa, S. Oguma, and K. Yamauch., J. Appl. Phys., 64, No. 10: 6044 (1989). https://doi.org/10.1063/1.342149

10. V.V. Maslov, V.K. Nosenko, L.Ye. Taranenko, and A.P. Brovko, Fiz. Met. Metalloved., 91: 47 (2001) (in Russian).

11. U. Kцster, U. Schьnemann, M. Blank-Bewersdorff, S. Brauer, M. Sutton, and G.B. Stephenson, Mat. Sci. Eng. A, 133: 611 (1991). https://doi.org/10.1016/0921-5093(91)90146-E

12. N.I. Noskova, N.F. Vil'danov, R.I. Kuznetsov, R.I. Tagirov, and A.A. Glazer, Fiz. Met. Metalloved., 65: 669 (1988) (in Russian).

13. G.E. Abrosimova, A.S. Aronin, S.V. Dobatkin, I.I. Zver'kova, D.V. Matveev, and O.G. Rybchenko, Phys. Metals Metallogr., 106: 597 (2008). https://doi.org/10.1134/S0031918X08120089

14. Zs. Kovacs, P. Henits, A. P. Zhilyaev, and A. Revesz, Scr. Mater., 54, No. 10: 1733 (2006). https://doi.org/10.1016/j.scriptamat.2006.02.004

15. N. Boucharat, R. Hebert, H. Rцsner, R. Valiev, and G. Wilde, Scr. Mater., 53, No. 7: 823 (2005). https://doi.org/10.1016/j.scriptamat.2005.06.004

16. M.L. Trudeau and R. Schulz, Phys. Rev. Lett., 64, No. 1: 99 (1990). https://doi.org/10.1103/PhysRevLett.64.99

17. F.Q. Guo and K. Lu, Metall. Mater. Trans. A, 28: 1123 (1997). https://doi.org/10.1007/s11661-997-0278-0

18. G.J. Fan, M.X. Quan, Z.Q. Hu, W. Lцser, and J. Eckert, J. Mater. Res., 14, No. 9: 3765 (1999).

https://doi.org/10.1557/JMR.1999.0510

19. B. Yao, S.-E. Liu, L. Liu, L. Si, W.-H. Su, and Y. Li, J. Appl. Phys., 90, No. 3: 1650 (2001). https://doi.org/10.1063/1.1385354

20. C. Zhang, Z. Zhang, Z. Qi, Y. Qi et al., J. Non-Cryst. Solids, 354, No. 32: 3812 (2008). https://doi.org/10.1016/j.jnoncrysol.2008.05.003

21. T. Gheiratmand, M.H.R. Hosseini, P. Davami, G. Ababei, and M. Song, Metall. Mater. Trans. A, 46: 2718 (2015). https://doi.org/10.1007/s11661-015-2848-x

22. A.G. Il'inskij, A.P. Brovko, G.M. Zelinskaya, N.S. Kosenko, T.M. Khristenko, G.F. Kobzenko, and A.A. Shkola, Metallofizika, 10, No. 2: 34 (1988) (in Russian). 
23. G.M. Zelinskaya, L.Ye. Mikhaylova, A.P. Brovko, and A.V. Romanova, Metallofizika, 14: 111 (1992) (in Russian).

24. Amorfnyye Metallicheskie Splavy [Amorphous Metal Alloys] (Eds. V.V. Nemoshkalenko et al.) (Kiev: Naukova Dumka: 1987) (in Russian).

25. A.V. Romanova, Metallofiz. Noveishie Tekhnol, 17: 3 (1995) (in Russian).

26. A.G. Il'inskiy, G.M. Zelinskaya, V.V. Maslov, V.K. Nosenko, and Yu.V. Lepeyeva, Metallofiz. Noveishie Tekhnol., 26: 1501 (2004) (in Russian).

27. G.M. Zelinskaya, V.V. Maslov, D.Yu. Paderno, A.V. Romanova, and A.V. Melezhik, Metallofizika, 14, No. 6: 45 (1992) (in Russian).

28. G.M. Zelinskaya, T.M. Khristenko, and A.V. Romanova, Metallofiz. Noveishie Tekhnol., 23: 961 (2001).

29. A.M. Glezer, M.R. Plotnikova, R.V. Sundeyev, and N.A. Shurygina, Izvestiya RAN. Ser. Fizicheskaya, 77: 1687 (2013) (in Russian).

30. G.E. Abrosimova, A.S. Aronin, S.V. Dobatkin, S.D. Kaloshkin, D.V. Matveev, O.G. Rybchenko, E.V. Tatyanin, and I.I. Zverkova, J. Metastable Nanocryst. Mater., 24-25: 69 (2005).

https://doi.org/10.4028/www.scientific.net/JMNM.24-25.69

31. W. Li, X. Li, D. Guo, K. Sato, D.V. Gunderov, V.V. Stolyarov, and X. Zhang, Appl. Phys. Lett., 94, No. 23: 231904 (2009).

https://doi.org/10.1063/1.3152013

32. A.M. Glezer, I.Ye. Permyakova, V.V. Gromov, and V.V. Kovalenko, Mekhanicheskoye Povedenie Amorfnykh Splavov [Mechanical Behaviour of Amorphous Alloys] (Novokuznetsk: Izd-vo SibGIU: 2006) (in Russian).

33. A.M. Glezer, B.V. Molotilov, and O.L. Utevskaya, Dokl. AN SSSR, 283: 106 (1985) (in Russian).

34. A.A. Rusakov, Rentgenografiya Metallov [Roentgenography of Metals] (Moscow: Atomizdat: 1977) (in Russian).

35. B. Huang, R.J. Perez, P.J. Crawford, A.A. Sharif, S.R. Nutt, and E.J. Lavernia, Nanostruct. Mater., 5, No. 5: 545 (1995). https://doi.org/10.1016/0965-9773(95)00261-C

36. T. Gheiratmand, H.R. Madaah Hosseini, P. Davami, M. Gjoka, and M. Song, J. Magnet. Mater., 381: 322 (2015).

https://doi.org/10.1016/j.jmmm.2015.01.016

37. G.J. Fan, M.X. Quan, and Z.Q. Hu, J. Appl. Phys., 80, No. 10: 6055 (1996). https://doi.org/10.1063/1.363563

38. M.O. Vasiliev, V.O. Tin'kov, Yu.M. Petrov, S. M. Voloshko, G.G. Galstyan, V.T. Cherepin, and A.S. Khodakivskyy, Metallofiz. Noveishie Tekhnol., 35, No. 5: 667 (2013) (in Russian).

39. B.N. Mordyuk and G.I. Prokopenko, J. Sound Vibration, 308, Nos. 3-5: 855 (2007). https://doi.org/10.1016/j.jsv.2007.03.054

40. N.A. Shurygina, A.M. Glezer, I.Ye. Permyakova, and Ye.N. Blinova, Izvestiya RAN. Ser. Fizicheskaya, 76: 52 (2012).

41. H. Chen, Y. He, G.J. Shiflet, and S.J. Poon, Nature, 367: 541 (1994). https://doi.org/10.1038/367541a0

42. W.H. Jiang and M. Atzmon, Acta Mater., 51, No. 14: 4095 (2003). https://doi.org/10.1016/S1359-6454(03)00229-5

43. J.-J. Kim, Y. Choi, S. Suresh, and A.S. Argon, Science, 295, No. 555: 654 (2002). https://doi.org/10.1126/science.1067453

44. A.M. Glezer, M.R. Plotnikova, R.V. Sundeyev, and N.A. Shurygina, Izvestiya RAN. Ser. Fizicheskaya, 77: 1687 (2013) (in Russian).

45. A.M. Glezer and B.V. Molotilov, Struktura i Mekhanicheskie Svoistva Amorfnykh Splavov [Structure and Mechanical Properties of Amorphous Alloys] (Moscow: Metallurgiya: 1992) (in Russian). 
46. V.P. Alekhin and V.A. Khonik, Struktura i Fizicheskie Zakonomernosti Deformatsii Amorfnykh Splavov [Structure and Physical Regularities of Deformation of Amorphous Alloys] (Moscow: Metallurgiya: 1992) (in Russian).

47. P.G. Zielinsky and D.G. Ast, Phil. Mag. A, 48, No. 5: 811 (1983). https://doi.org/10.1080/01418618308236546

48. C.A. Pampillo, J. Mater. Sci., 10: 1194 (1975). https://doi.org/10.1007/BF00541403

49. T. Masumoto, Sci. Rep. Res. Inst. Tohoku Univ. Ser. A, 26: 246 (1977).

50. F. Meng, K. Tsuchiya, S. Ii, and Y. Yokoyama, Appl. Phys. Lett., 101, No. 12: 121914 (2012). https://doi.org/10.1063/1.4753998

51. F. Spaepen, Acta Metall., 25, No. 4: 407 (1977). https://doi.org/10.1016/0001-6160(77)90232-2

52. A.S. Argon, Acta Metall., 27, No. 1: 47 (1979). https://doi.org/10.1016/0001-6160(79)90055-5

53. M.L. Trudeau, J.Y. Huot, R. Schulz, D. Dussault, A. Van Neste, and G. L'Espérance, Phys. Rev. B, 45, No. 9: 4626 (1992). https://doi.org/10.1103/PhysRevB.45.4626

54. C. Bansa, B. Fultz, and W.L. Johnson, Nanostruct. Mater., 4, No. 8: 919 (1994). https://doi.org/10.1016/0965-9773(94)90098-1

55. Y.He, G.J. Shiflet, and S.J. Poon, Acta Metall. Mater., 43, No. 1: 83 (1995). https://doi.org/10.1016/0956-7151(95)90264-3

56. J. Xu and M. Atzmon, Appl. Phys. Lett., 73, No. 13: 1805 (1998). https://doi.org/10.1063/1.122288

57. S.M. Bokoch, M.P. Kulish, T.M. Radchenko, and V.A. Tatarenko, Metallofiz. Noveishie Tekhnol., 26, No. 3: 387 (2004) (in Russian).

58. S.M. Bokoch, M.P. Kulish, V.A. Tatarenko, and T.M. Radchenko, Metallofiz. Noveishie Tekhnol., 26, No. 4: 541 (2004) (in Russian).

59. V.A. Tatarenko and T.M. Radchenko, Defect Diffus. Forum, 194-199, part 1: 183-188 (2001).

https://doi.org/10.4028/www.scientific.net/DDF.194-199.183

60. T.M. Radchenko, V.A. Tatarenko, and S.M. Bokoch, Metallofiz. Noveishie Technol., 28, No. 12: 1699 (2006).

61. V.A. Tatarenko and T.M. Radchenko, Usp. Fiz. Met., 3, No. 2: 111 (2002) (in Ukrainian). https://doi.org/10.15407/ufm.03.02.111

62. V.V. Maslov, A.G. Il'inskiy, V.K. Nosenko, A.P. Brovko, and I.K. Yevlash, Metallofiz. Noveishie Tekhnol., 22, No. 3: 43 (2000) (in Russian).

63. O.G. Il'inskyy, V.L. Karbivs'kyy, A.P. Shpak, and Yu.V. Lepeeva, Nanosistemi, Nanomateriali, Nanotehnologii, 8, No. 3: 483 (2010) (in Russian).

64. A.D. Alexeev, G.M. Zelinskaya, A.G. Il'insky, I.G. Kaban, Yu.V. Lepeyeva, G.S. Mogilny, E.V. Ulyanova, and A.P. Shpak, Fizika i Tekhnika Vysokikh Davleniy, 18, No. 3: 35 (2008) (in Russian).

65. A.M. Glezer, S.V. Dobatkin, M.R. Plotnikova, and A.V. Shalimova, Mater. Sci. Forum., 584-586: 227 (2008).

https://doi.org/10.4028/www.scientific.net/MSF.584-586.227

66. B. Yang, C.T, Liu, T.G. Nieh, M.L. Morrison, P.K. Liaw, and R.A. Buchanan, J. Mater. Res., 21, No. 4: 915 (2006).

https://doi.org/10.1557/jmr.2006.0124

67. J.J. Lewandowski and A.L. Greer, Nature Mater., 5: 15 (2006).

https://doi.org/10.1038/nmat1536 
68. F. Spaepen, Nature Mater., 5: 7 (2006). https://doi.org/10.1038/nmat1552

69. A.M. Glezer, S.G. Zaychenko, and M.R. Plotnikova, Izvestiya RAN. Ser. Fizicheskaya, 76: 63 (2012).

70. V.G. Gryaznov, A.Ye. Kaprelov, and A.Ye. Romanov, Pis'ma $v$ ZhETF, 15: 1256 (1989) (in Russian).

71. A. Mazilkin, B. Straumal, A. Kilmametov, P. Straumal, and B. Baretzky, Mater. Trans., 60, No. 8: (2019). https://doi.org/10.2320/matertrans.MF201938

72. A.A. Csontos and G.J. Shiflet, Nanostruct. Mater., 9, Nos. 1-8: 281 (1997). https://doi.org/10.1016/S0965-9773(97)90068-4

73. M.L. Trudeau, L. Dignard-Bailey, R. Schulz, D. Dusdault, and A. Van Neste, Nanostruct. Mater., 2, No. 4: 361 (1993). https://doi.org/10.1016/0965-9773(93)90177-D

74. Amorphous Metallic Alloys (Ed. F.E. Luborsky) (Oxford: Butterworth-Heinemann, Elsevier: 1983).

https://doi.org/10.1016/C2013-0-05075-X

75. C. Suryanarayana and A. Inoue, Bulk Metallic Glasses (Boca Raton, FL: Taylor \& Francis Group, LLC: 2018).

76. K. Miyoshi and D.H. Buckley, Thin Solid Films, 118, No: 3: 363 (1984). https://doi.org/10.1016/0040-6090(84)90206-2

77. G. Mazzone, A. Montone, and M.V. Antisari, Phys. Rev. Lett., 65, No. 16: 2019 (1990). https://doi.org/10.1103/PhysRevLett.65.2019

78. W.H. Jiang, F.E. Pinkerton, and M.J. Atzmon, J.Appl. Phys., 93, No. 11: 9287 (2003).

https://doi.org/10.1063/1.1571234

Received 02.08.2019;

in final version, 10.07.2020

М.О. Васильєв ${ }^{1,2}$, В.К. Носенко ${ }^{1}$, І.В. Загорулько ${ }^{1}$, С.М. Волошко ${ }^{2}$

${ }^{1}$ Інститут металофізики ім. Г.В. Курдюмова НАН України, бульв. Академіка Вернадського, 36, 03142 Київ, Україна

${ }^{2}$ Національний технічний університет України «Київський політехнічний інститут імені Ігоря Сікорського», просп. Перемоги, 37, 03056 Київ, Україна

\section{НАНОКРИСТАЛІЗАЦІЯ АМОРФНИХ СТОПІВ} НА ОСНОВI Fе ЗА ІНТЕНСИВНОЇ ПЛАСТИЧНОЇ ДЕФОРМАЦІЇ

Оглядаються літературні дані з проблеми модифікації структури та властивостей швидкозагартованих стопів на основі Fе різними методами інтенсивної пластичної деформації (ІПД). Розглянуто такі способи ІПД як кручення у камері Бріджмена, оброблення у кульових млинах і високочастотне ударне оброблення, а також їхні переваги та недоліки. На прикладі великої кількости аморфних стопів на основі $\mathrm{Fe}$ проаналізовано вплив кожного з розглянутих методів ІПД на їхню структуру та властивості. На основі одержаних даних запропоновано механізм деформаційної нанокристалізації аморфних стопів.

Ключові слова: аморфні стопи, інтенсивна пластична деформація, смуги зсуву, нанокристалізація, механічні властивості. 